\title{
A PROTEÇÃO DOS REFUGIADOS NO BRASIL, QUESTÕES DE GÊNERO E TRATAMENTO DA DIGNIDADE DA PESSOA HUMANA: UMA ANÁLISE NA CIDADE DE SÃO PAULO
}

\author{
Renan Antônio da Silva ${ }^{1}$ \\ Renato Ribeiro Nogueira Ferraz ${ }^{2}$ \\ Gabriel Oliveira Nascimento da Silva ${ }^{3}$
}

Resumo: $\mathrm{O}$ artigo científico tem como escopo a análise do tema sobre a proteção dos refugiados no Brasil combinada com a análise da dignidade da pessoa humana e gênero na cidade de São Paulo. A metodologia utilizada foi a qualitativa de acordo com uma revisão bibliográfica que verificou doutrinas em direitos humanos, constitucional, análise de artigos científicos, matérias publicadas no meio jornalístico e dados apresentados pelas instituições de atendimento aos refugiados. Dividido em três capítulo, o trabalho tem como objetivo geral conceituar a dignidade da pessoa humana e explorar o arsenal que a Constituição Federal de 1988 possui, afirmando as formas inclusivas de recebimentos dos refugiados. Em um segundo momento demonstra-se a historicidade que cerca os refugiados e a busca pelo tratamento digno desde a saída do país de origem até $o$ reestabelecimento no país refugiado. $\mathrm{O}$ objetivo específico do trabalho é alcançado ao demonstrar as políticas públicas na cidade de São Paulo, em destaque para o Instituto de Reintegração do Refugiado, o Cáritas Brasileira com a criação do Centro de Acolhida a Refugiados e a atuação do Conselho Municipal do Imigrante que fiscaliza a

\footnotetext{
${ }^{1}$ Pós - Doutor pelo Programa de Pós - Graduação em Ciências Sociais da Universidade Estadual Paulista Júlio de Mesquita Filho - UNESP (2019). Bolsista de Pós - Doutorado (PNPD) da CAPES pelo Programa de Pós-Graduação em Políticas Públicas (PPG-PP) da Universidade de Mogi das Cruzes (UMC), onde é credenciado como Docente Permanente (orientador de mestrado). Doutor em Educação Escolar (2018) pela Universidade Estadual Paulista (UNESP/ Araraquara).

${ }^{2}$ Possui Pós-Doutorado em Ciência da Informação e da Comunicação (2019), pela Université de Toulon - França, Pós-Doutorado (2013) e Doutorado em Ciências Básicas (2007), pela Universidade Federal de São Paulo - UNIFESP. É Mestre em Ciências Básicas (2003), também pela UNIFESP. Graduou-se em Pedagogia (2010) pela Universidade Nove de Julho - UNINOVE, em Ciências Biológicas - Bacharelado (2001) pela Universidade do Grande ABC - UNIABC, e em Ciências Biológicas - Licenciatura Plena (1999), também pela UNIABC.

${ }^{3}$ Bacharel em Direito pela Universidade de Mogi das Cruzes - UMC
} 
aplicação das políticas públicas a fim de incluírem e disseminarem atitudes preconceituosas e discriminatórias na sociedade.

Palavras-Chave: Refugiados.

Dignidade. Tratamento. Cidade. Inclusão.

Abstract: The scientific article has as its scope the analysis of the theme on refugee protection in Brazil combined with the analysis of human dignity and gender in the city of São Paulo. The methodology used was the qualitative one according to a bibliographical revision that verified doctrines in human rights, constitutional, analysis of scientific articles, articles published in the journalistic environment and data presented by institutions of assistance to refugees. Divided into three chapters, the general objective of the paper is to conceptualize the dignity of the human person and to explore the arsenal of the 1988 Federal Constitution, stating the inclusive forms of receiving refugees. In a second moment the historicity that surrounds the refugees and the search for the treatment dignified from the exit of the country of origin until the reestablishment in the refugee country is demonstrated. The specific objective of the work is achieved by demonstrating public policies in the city of São Paulo, highlighting the Institute for Reintegration of Refugees, Caritas Brasileira with the creation of the Refugee Reception Center and the work of the Immigrant Municipal Council that supervises the application of public policies to include and disseminate prejudiced and discriminatory attitudes in society.

Keywords: Refugees. Dignity. Treatment. City. Inclusion.

\section{Introdução}

Este trabalho teve como tema a proteção dos refugiados no Brasil e o tratamento da dignidade da pessoa humana voltado para uma análise na cidade de São Paulo, de acordo com os métodos inclusivos das entidades públicas e privadas que promovem a integração e a busca pelo atendimento ao bem-estar e reconstrução da dignidade.

O objetivo geral do trabalho foi demonstrar a conceituação da dignidade da pessoa humana em razão de uma problemática abarcada nas formas com que os refugiados são tratados em solo 
brasileiro quando chegam dos seus países de origem, promovendo a inclusão, tanto na sociedade, como no mercado de trabalho e verificando os mecanismos para o fim da discriminação e preconceito nesta seara.

Mais adiante, o objetivo específico foi analisar as entidades da cidade de São Paulo que atendem os refugiados que lá moram, sendo um dos maiores antros de receptividade dessas pessoas, com o escopo de trazer, de forma digna, a inclusão, o ensinamento da língua portuguesa, os métodos de profissionalização e inserção no mercado de trabalho e o atendimento dos direitos fundamentais pautados na Constituição Federal de 1988.

Portanto, no primeiro capítulo foi tratado sobre a dignidade da pessoa humana na Constituição Federal de 1988 e a análise das doutrinas em direito constitucional e humanos, definindo e conceituando tal princípio; demonstrouse em outro momento o arsenal que a Constituição possui que pode ser voltado para os refugiados, como é o caso da isonomia material e formal e a apresentação dos instrumentos nacionais e internacionais dos direitos humanos destinados aos imigrantes, deslocados e refugiados.
No segundo capítulo, possuindo uma carga histórica alta, demonstra-se a necessidade de apresentar o que os refugiados precisam para que encontrem o tratamento digno no país de refúgio face ter sido violada no país de origem, procurando reestabelecer-se de forma inclusiva e com oportunidades iguais para todos. Sobre o asilo e o refúgio, a fim de diferenciação e conceituação que são diferentes no ordenamento jurídico brasileiro foi demonstrada e, mais à frente, o acolhimento do Brasil aos refugiados fez-se importante.

Por fim, explora-se os dados que as matérias jornalísticas e do Sistema Nacional de Cadastros e Registros de Estrangeiros divulgaram, além de apresentar as políticas públicas de atendimento aos refugiados e, por fim, o diferencial do Conselho Municipal do Imigrante, elogiado pela ONU, que vem trazendo competências para formulação, implementação e avaliação das políticas públicas municipais em São Paulo.

\section{Análise da dignidade da pessoa humana - princípio e definições da doutrina e jurisprudência}

A dignidade da pessoa humana está presente na Constituição Federal de 
1988, inicialmente, como fundamento da República Federativa do Brasil no artigo $1^{\circ}$, inciso III, além de vir afirmando que toda a ação econômica terá como finalidade assegurar a todos uma existência digna, conforme o artigo 170. Mais adiante, no texto, o parágrafo sétimo do artigo 226 determina que o planejamento familiar é de livre decisão do casal e fundado no princípio da dignidade da pessoa humana. Já no que se relaciona o artigo 227, há a consideração de que caberá à família, à sociedade e ao Estado assegurar à criança, ao adolescente e ao jovem a dignidade. Mais à frente, o artigo 230 conclui que prevê à família, à sociedade e ao Estado o dever de amparar as pessoas idosas, sempre sob a defesa da dignidade e do bem-estar (BRASIL, 1988).

Ainda no plano nacional, tem-se que a primeira aparição da dignidade no Brasil ocorreu em 1934, por força da influência da Constituição Alemã de Weimar do ano de 1919, fazendo presente justamente no âmbito dos princípios da ordem econômica e social, mais precisamente no que se refere ao artigo 115 do texto que continha que "ordem econômica deve ser organizada conforme os princípios da justiça e as necessidades da vida nacional, de modo que possibilite a todos existência digna. Dentro desses limites é garantida a liberdade econômica" (BRASIL, 1934), indicando, como explicou Sarlet (2018, p. 276) que o legislador constituinte da época atribuiu à dignidade uma função de que fosse o fundamento, mas também possuindo como limite da liberdade econômica brasileira.

Relatando-se, a Constituição de 1934 foi dentre as poucas que fizeram a expressa menção à dignidade da pessoa humana antes da viragem trazida pela Segunda Guerra Mundial, dentre os títulos está presente a Constituição de Weimar, de 1919, como já mencionada; a Constituição Portuguesa do ano de 1933 e a Constituição da Irlanda de 1937. Sarlet (2018, p. 277) ainda mencionou que após o período da guerra, a dignidade da pessoa humana foi sendo associada paulatinamente, não somente no campo das legislações como da literatura, com os direitos humanos e fundamentais reconhecidos em uma esfera internacional e constitucional.

Presente no plano internacional, inclusive, a dignidade possui, atualmente, seu lugar de destaque no que se refere a Declaração Universal de Direitos Humanos, no preâmbulo, 
conduz o ensinamento de que há a necessidade de proteção da dignidade humana por meio da proclamação dos direitos ali elencados, estabelecendo no artigo $1^{\circ}$ que "todos os seres humanos nascem livre e iguais, em dignidade e direitos" (FRANÇA, 1948).

Em dois outros pactos internacionais que foram ratificados pelo Brasil, há o Decreto nº 592, de 6 de julho de 1992, sobre os direitos civis e políticos e o Decreto $\mathrm{n}^{\circ} 591$, promulgado na mesma data, o Pacto Internacional sobre os Direitos Econômicos, Sociais e Culturais. Os dois títulos trataram do reconhecimento da dignidade sendo inerente a todos os membros da família humana (BRASIL, 1992).

Após a explanação da localização nas legislações nacionais e internacionais que mencionam a dignidade no ordenamento jurídico brasileiro, Ramos (2018, p. 83) assevera que a raiz da palavra "dignidade" está ligada ao que vem de dignus e referindose aquilo que possui honra ou importância, consistindo, assim, na qualidade intrínseca e distinta de cada ser humano, o que vem a ser a proteção contra os tratamentos humilhantes, degradantes ou que advém de uma discriminação odiosa, assegurando, dessa forma, as condições materiais mínimas para sobrevivência.

Em outra linha de pensamento, mas não diferindo sobre o interior do princípio, Barroso (2014, p. 13) afirma que a dignidade vem de dignitas, remonta a Roma antiga e atravessa a Idade Média, seguindo até o Estado Liberal, sendo um conceito que estava associado ao status de alguns indivíduos. No sentido pré-moderno, de acordo com o autor, a dignidade era usada no sentido de uma sociedade hierarquizada, na qual a desigualdade entre as pessoas era categorizada entre os indivíduos e os arranjos institucionais que eram vividos, sendo que era equivalente à nobreza, implicando em um tratamento especial com direitos e privilégios exclusivos.

A ideia contemporânea de dignidade, segundo o autor, é aquela que liga-se ao desenvolvimento histórico do conceito romano de dignita hominis, incorporado aos documentos internacionais, tratados e das constituições que ao longo do tempo foram surgindo fundamentadas na liberdade e na igualdade - acrescentando o terceiro ditame, a fraternidade (ou solidariedade) - , assentando-se em diferenciações conceituais atualmente. Barroso (2014, p. 14) continua que o 
conceito de dignidade humana na sociedade contemporânea traz ao homem o pressuposto de possuir um valor intrínseco e que desfruta de uma posição especial no universo.

Conclui, na mesma seara de estudo que levou Barroso, Agra (2018, p. 155) elucida que o conceito de dignidade da pessoa humana não é um conceito que foi único ao longo do tempo, mas que foi consolidando-se como tal com o passar da história e dos acontecimentos ocorridos, principalmente após a Segunda Guerra Mundial.

Deve-se levar em consideração, como aduz o autor, que a dignidade da pessoa humana é inata, inalienável e absoluta, devendo ser propiciadas as situações de vivência desse princípio concedidas pelas ações positivas e negativas do Estado em relação aos direitos fundamentais e, consequentemente, as gerações dos direitos.

Entendeu o autor que são ações preexistentes a qualquer direito estatal e que advém da qualidade inata dos humanos em possuírem a dignidade atrelada às condições econômicas e que deve ser defendida. É por esta razão que a dignidade é utilizada como uma das justificativas ao acolhimento dos refugiados e das formas de garantia do bem-estar e das oportunidades que serão vistas ao longo do desenvolvimento do trabalho.

Não houve inserção direta da dignidade da pessoa humana no rol dos direitos fundamentais que estão, em sua maioria, no artigo $5^{\circ}$ da Constituição Federal de 1988. A opção do legislador constitucional foi de inserir a dignidade como um dos fundamentos da República Federativa do Brasil, para Tavares (2017, p. 441) há a ideia de que o objetivo era que a pessoa seja tanto um fundamento como o fim da sociedade, não podendo ser, como acontece com o Estado, um meio e não um fim, pois assim, justifica-se que o Estado existe em função de todas as pessoas, e não estas estão em função do Estado. Esta concepção decorre, inicialmente, do cristianismo, mudando de sentido ao longo do tempo, dando ensejo não somente através da religião, como com uma validade universal, além da forma emotiva que se destaca com grandes concepções morais em determinados títulos legislativos e decisões jurisprudenciais quando ensejam nas decisões sobre o ferimento ou não da dignidade da pessoa humana. 
$O$ arsenal da constituição federal de 1988 voltado para os refugiados

Visto anteriormente que a Constituição Federal de 1988 traz a todos os homens a dignidade da pessoa humana, deve-se entender que esse arsenal jurídico de ditames de direitos fundamentais também recai aos instrumentos de proteção nacional e internacional de Direitos Humanos, face todos os títulos legislativos serem aprovados pelo Brasil e devem estar em consonância com o que texto Maior, considerando como o necessário para constar nas leis.

É assim, neste sentido que Amorim e Barros (2017, p. 97) discutem que, em um mundo atualmente que se encontra sob os aspectos da mundialização - ou globalização - devese entender que é um espaço propício para que encontrem indeterminações de sentido e de significados e, que neste passo, os Estados, quando confrontados com a realidade, terão que lidar com um vazio institucional que, em muitas vezes, não foi assentado por ideologias ou utopias preestabelecidas no direito, de forma que em casos de crises de autoridade, legitimidade e representação, faz sentir em outros organismos multilaterais, como é o caso da Organização das Nações Unidas.

O que autores vem ressaltando é que a ONU, em algum momento, passou a tratar das enormes diversidades de problemas que a agenda internacional e foi impondo aos países-membros e que estes possuem, em sua maiorias, frágeis mecanismos para própria instauração de resoluções que são procuradas a instaurar e por isso que vem surgindo a dificuldade dos países em tratar da melhor maneira as situações que, até então, não tinham resolução nenhuma, pois não ocorriam em larga escala.

É o caso dos refugiados, pois, destacam os autores que é de acordo com que os governos, em particular, procurarão lidar com as transformações que ocorrem na ordem política, econômica, tecnológica, cultural e social quando processadas em escala global, é partir da forma com que for adotado o posicionamento do Estado que será percebido o desempenho na balança perante os direitos e garantias definidos aos homens.

Para melhor definição, os autores trazem o estudo do Direito Constitucional Internacional e que é conceituado por Mello (2000, p. 36) como sendo a união entre o direito 
constitucional e o direito internacional, sendo uma forma da Constituição de se adaptar à ordem jurídica internacional que a ela é sobreposta. Portanto, como a Constituição de um país é a manifestação da soberania estatal, o direito internacional público entra no sentido de haver uma negação, ou mesmo, uma crescente limitação a esta atuação.

Considera o autor, de forma crítica, não existia um Direito Constitucional Internacional por não ser um objeto definido e nem ser um método próprio, mas que dessa forma, existem normas constitucionais de alcance internacional e que deverão ser analisadas em cada caso em busca de compatibilidade dos direitos ali contidos.

Surge diante dessa discussão os direitos humanos fundamentais e em como age a interpretação conforme a Constituição quando se fala dos direitos dos refugiados sendo que é possível perceber, de acordo com Amorim e Barros (2017, p. 105) que a constituição elegeu como direitos e garantias fundamentais, os direitos e deveres individuais e coletivos; os direitos sociais; a nacionalidade; os direitos políticos e o regramento dos partidos políticos.
Neste sentido, Sarlet (2012, p. 190) conduz o ensinamento no sentido de trazer à pessoa natural como o titular dos direitos fundamentais elencados no texto constitucional, conforme o que trouxe o caput do artigo $5^{\circ}$, reconhecendo, por meio da dignidade da pessoa humana e dos princípios conexos entre a isonomia e a universalidade, a toda e qualquer pessoa, sendo essa pessoa brasileira ou estrangeira residente no país, recaindo todos os direitos.

Sobre a própria limitação do texto que traz sobre a residência no Brasil ou não, Sarlet (2012, p. 190) acha importante ressaltar que o Supremo Tribunal Federal veio trazendo a distinção entre os nacionais e os estrangeiros, designadamente no que diz respeito à cidadania e a nacionalidade.

Neste passo, brevemente, deve-se destacar rapidamente o princípio da isonomia. $\mathrm{O}$ artigo $5^{\circ}$ da Constituição Federal de 1988 em seu caput que avulta o princípio da isonomia dispondo que "todos são iguais perante a lei, sem distinção de qualquer natureza (...)", assegurando ainda a inviolabilidade do direito à igualdade (BRASIL, 1988).

No entanto, como elucida Vasconcelos (2017, p. 183), não é somente este caput mencionado que se 
pode visualizar o princípio da igualdade no ordenamento jurídico, mas também, diversos outros artigos do texto Maior, tratando-se dos seus pilares para aplicação.

Salienta-se, os objetivos da República Federativa do Brasil que consistem em redução das desigualdade sociais e regionais, conforme o inciso III do artigo $3^{\circ}$; a promoção do bem comum de todos sem quaisquer discriminações, instrui o inciso IV do mesmo artigo; a igualdade em direitos e obrigações entre os homens e as mulheres sem quaisquer discriminações, de acordo com o inciso I do artigo $5^{\circ}$; além da proibição de diferença de salários, de exercício de funções e de critérios de admissão por motivos de sexo, idade, cor ou estado civil, como alude o inciso XXX do artigo $7^{\text {o }}$; bem como a forma de proibição de discriminação quanto ao salário e os critérios de admissão do trabalhador portador de deficiência, ainda no artigo $7^{\circ}$, inciso XXXI, dentre outros dispositivos (BRASIL, 1988).

$$
\text { Vasconcelos (2017, p. 183) }
$$

aborda em sua obra o critério discriminatório, explicando, portanto, sendo que é importante entender que vem a ser igual ou desigual para identificar o que é lesão ao princípio da isonomia, encontrando-se na comparação entre $\mathrm{o}$ elemento de discriminação e $\mathrm{o}$ atingimento da finalidade do ato, no caso em concreto.

O universo da amostra é exposto por Mello afirmando:

tem-se que investigar, de um lado,
aquilo que é adotado como critério
discriminatório; de outro lado,
cumpre verificar se há justificativa
racional, isto é, fundamento
lógico, para, à vista do traço
desigualador acolhido, atribuir o
específico tratamento jurídico
construído em função da
desigualdade proclamada.
Finalmente, impende analisar se a
correlação ou fundamento racional
abstratamente existente é, in
concreto, afinado com os valores
prestigiados no sistema normativo
constitucional. A dizer: se guarda
ou não harmonia com eles
(MELLO, 2006, p. 21).

Coaduna Vasconcelos (2017, p. 186) com o pensamento de Mello no sentido de que, na ocasião em que ocorrer um fator de discriminação, se este for utilizado e não estiver em conformidade com o fim colimado, a discriminação será inválida, consequentemente, será inconstitucional, sendo que é essencial o entendimento do operador do direito em perceber a estrita ligação entre esses dois elementos.

Porém, explica o autor, se o fator de discriminação estiver alinhado com o objetivo a ser traçado, a discriminação é 
válida e constitucional, como é o exemplo utilizado em concurso público. Em amostragem, se um concurso público for aberto para preenchimento de vagas para Delegado de Polícia e no interior do edital mencionar que não poderão participar candidatos com menos de 1,60 cm de altura, ocorrerá discriminação, pois essa exigência em questão não interfere no desempenho adequado para o cargo. Porém, se o concurso é aberto para preenchimento de guarda de honra do Presidente da República e o edital constar que somente pessoas com a altura acima de $1,70 \mathrm{~cm}$ poderão ser selecionadas, este critério discriminatório será o mesmo, mas neste caso, é válida a discriminação, pois a altura para este cargo em específico é importante (VASCONCELOS, 2017, p. 186).

O exemplo é importante, pois no caso concreto deve-se analisar a determinada discriminação, se esta é gratuita ou não. A constatação de Vasconcelos (2017, p. 186) leva às formas de relação de compatibilizar a discriminação e o objetivo da norma, aproximando o princípio da isonomia ao da razoabilidade, devendo obedecer às regras simples.
A primeira é verificar a circunstância discriminada - o fator de discriminação; a segunda trata-se da verificação do objetivo da norma, se este objetivo é constitucional ou não; a terceira, deve-se estabelecer um nexo de logicidade entre as circunstâncias da discriminação e o objetivo da norma, ou seja, analisar quando $\mathrm{o}$ fato de discriminação estiver de acordo com o escopo a ser atingido no caso concreto, percebendo se fere a isonomia, porém, uma discriminação válida; quando o fator da discriminação será utilizado no caso concreto não está de acordo com o objetivo da norma e, portanto, é inválida a discriminação; e por fim, se são inconstitucionais as discriminações gratuitas - aquelas que não possuem lógica ou relação com o objetivo da norma (VASCONCELOS, 2017, p. 186).

O que Mota e Spitzcovsky (2004, p. 470) frisam é outro exemplo importante e que condiz com o estudo do objetivo específico do presente do trabalho, conduzindo uma situação de igualdade que pode ser mencionada quando se trata dos refugiados. Dessa forma, é possível perceber que no caso brasileiro, embora possuir carências e privações da população solicitante e dos 
refugiados no Brasil, estes possuem o acesso às políticas públicas de saúde $\mathrm{e}$ educação na mesma medida em que os brasileiros, em pé de igualdade, bem como o que ocorre com o direito ao trabalho.

Importante constatar que a igualdade constitui para o direito constitucional contemporâneo como um valor central, representando uma real "pedra angular", como discute Sarlet (2017, p. 615), sendo parte integrante da tradição constitucional que é inaugurada com as primeiras declarações de direitos e da incorporação de catálogos constitucionais, desde o constitucionalismo de matriz liberalburguesa, até os dias atuais.

Na mesma seara, Ferreira Filho (2012, p. 239) considera que a igualdade é princípio inerente à democracia e que, desde a Antiguidade, é indissolúvel e deve ser associada à democracia e "da mesma forma, não se pode modernamente caracterizar a democracia sem que se abra lugar para a igualdade, embora esse lugar não seja sempre o mesmo".

Como anotou Mendes (2007, p. 146), salienta-se que "a nacionalidade configura vínculo político e pessoal que se estabelece entre o Estado e o indivíduo, fazendo com que este integre uma dada comunidade política, o que faz com que o Estado distinga o nacional do estrangeiro para diversos fins".

O que se tem é que o sistema jurídico internacional possui como escopo a proteção dos direitos dos refugiados, relacionando-se com os princípios que integram o papel essencial de estruturamento do ordenamento jurídico por meio das convicções fraternais sobre $\mathrm{o}$ acolhimento $\mathrm{da}$ comunidade social, garantindo coerência entre as normas e a atribuição dos direitos fundamentais a eles.

Sobre esse contexto, é possível concordar com o que Alexy (2014, p. 141) abarcou no sentido de existir uma primazia dos direitos fundamentais em relação aos demais direitos existentes dado o grau de importância concedido à dignidade da pessoa humana.

A situação dos refugiados perante as proteções concedidas diante do que a construção da Constituição Federal do Brasil de 1988 abarca é que há uma globalização vertical, como considerou Mendes e Branco (2016, p. 659) em sua doutrina, afirmando que as normas internacionais, quando trazem aos refugiados a atribuição de direitos especiais nos respectivos ordenamentos 
jurídicos nacionais, é o reflexo de regime jurídico claramente diferenciado ao que se concede aos estrangeiros, sendo que ao analisar a Lei $\mathrm{n}^{\circ}$ 9.474, de 10 de setembro de 1997, definiu mecanismos importantes para o Brasil e para a implantação do Estatuto dos Refugiados de 1951.

\section{Instrumentos de proteção nacional e internacional dos direitos humanos destinados aos imigrantes, deslocados e refugiados}

Há presente no ordenamento jurídico diversos mecanismos de proteção nacional e internacional voltados para os imigrantes, deslocados e refugiados. Primeiramente, será definido, de acordo com a doutrina constitucional, o que são os estrangeiros, a questão da residência ou não, além da discussão que cerca tal problemática no Brasil.

Sustenta Mendes e Branco (2016, p. 654) que o estrangeiro poderá estar no Brasil em caráter permanente, com o propósito de fixar residência definitiva ou estar em caráter temporário em solo nacional, independentemente, como destaca o autor, do seu status ou do objetivo da viagem, seja essa visita a lazer ou a trabalho, reconhece-se ao estrangeiro os direitos garantias básicas da pessoa humana, ou seja, a integridade, a vida, o direito de petição, a dignidade da pessoa humana, o contraditório e ampla defesa, dentre outros.

Na Constituição Federal de 1988, há a consideração no artigo 22 , inciso XV a disciplina sobre a emigração e imigração, entrada e extradição, bem como a expulsão de estrangeiros, sendo que a competência legislativa privativa é da União, ou seja, somente a União poderá legislar relacionado a este assunto (BRASIL, 1988).

Mendes e Branco (2016, p. 654) ainda vieram elucidando que aos estrangeiros reconhece-se o gozo dos direitos civis, com exceção do direito ao trabalho remunerado, apenas reconhecido ao estrangeiro residente, assim, a aquisição ou arrendamento de propriedade rural também será assegurada ao estrangeiro, mesmo que possua algumas condicionantes, como há a limitação da dimensão da área e da residência no território nacional, de acordo com o que reza o artigo 190.

Sobre direitos políticos, os estrangeiros, de acordo com o artigo 172, não terão esses direitos, não sendo possível votar ou serem eleitos para 
cargos políticos, sobre os direitos de cidadania para a propositura de ação popular e de subscrição de projetos de lei de iniciativa popular, também são vedados e a eles não recaem esses direitos específicos.

De acordo com as informações trazidas na matéria publicada por Enriconi (2017) os imigrantes serão aquelas pessoas que se deslocam e, em geral, de forma voluntária do país de origem para outro, com o intuito de estabelecer-se por um tempo previamente determinado, pode ser por meio do trabalho, a lazer ou em missões específicas.

Os asilados políticos, como são chamados, de acordo com Enriconi (2017) são aqueles que estão sendo perseguidos por motivos políticos no seu país de origem e, em razão disso, solicitam a outro país que este venha a acolhê-lo e protegê-lo das ameaças que vem sofrendo.

E por fim, os refugiados, para a autora, são aqueles que podem ser frequentemente confundidos com os asilados, pois ambos envolvem algum tipo de perseguição, entretanto, difere-se por estes serem em razão de perseguições étnicas, em razão da religião, nacionalidade, grupo social, convicção política, dentre outros motivos.

Assim:

Outra grande diferença é que, enquanto a decisão de receber um asilado político é exclusivamente do Estado, consistindo em uma relação direta deste com o indivíduo, o refugiado faz parte de um grupo que sofre perseguição por um mesmo motivo, não cabendo ao Estado decidir de forma política acolher ou não esses indivíduos que chegam a seu território após fugir de uma situação de risco. A regulamentação internacional referente ao refúgio se baseia principalmente na Convenção de Genebra de 1951, que, dentre outros benefícios, garante aos refugiados o direito de não serem expulsos ou retornados a seus países de origem enquanto permanecerem os riscos à sua vida ou liberdade (ENRICONI, 2017).

$\mathrm{Na}$ seara de tratamento dos refugiados, de acordo com o que fora visto anteriormente, portanto, há o princípio da "não devolução" como é destacado pelos artigos 33 da Convenção de 1951; no artigo 22, inciso VII da Declaração Americana de Direitos Humanos e a $3^{\text {a }}$ Convenção das Nações Unidas, sendo um dos princípios norteadores dos direitos dos refugiados que traz a ideia de garantir a eles que não serão devolvidos ao seu país de origem, 
pois de lá saiu ou fugiu por motivos de perseguição e que deu origem a sua condição, bem como, para qualquer outro país que sua vida ou a liberdade estejam em risco.

Sobre esse direito Piovesan (2001, p. 50) vem considerando que a não devolução do refugiado passa a ser um princípio geral de direito internacional e que tanto no direito dos refugiados como nos direitos humanos, deve ser reconhecido e respeitado de qualquer forma, tratando, inclusive, como explica Saadeh (1998, p. 24) que a devolução poderá ser entendida como uma prática ilegal pelo Estado, sem que haja, inicialmente, um estudo e análise formal do pedido do refúgio na fronteira ou quando, já dentro do território, deixando-o desprotegido e que fique à mercê de perseguições e desamparo, infringindo diretamente a dignidade.

Mais adiante, o princípio da unidade familiar, como incorre Pereira (2009, p. 69) há a consideração de extensão da proteção a entidade que passa a ser igualmente contemplada em várias ordens jurídicas, ou seja, a família. Coaduna com essa disposição o que traz a Declaração Universal dos Direitos Humanos, afirmando que a família é elemento essencial e natural para que a sociedade se desenvolva, possuindo o direito à proteção do Estado (FRANÇA, 1948).

Diante dessa análise, portanto, verifica-se que dentro da legislação brasileira, com amparo também pela legislação internacional, são oferecidos diversos instrumentos de proteção nacional e internacional dos direitos humanos destinados aos imigrantes, deslocados e refugiados, colaborando com a busca pela inserção nos locais sociais, no mercado de trabalho e no acolhimento de forma geral.

\section{Os refugiados a necessidade do tratamento digno ao ser humano}

Após ser apresentada as conceituações sobre a dignidade da pessoa humana aos refugiados que foram tratadas no ordenamento jurídico brasileiro em face do amparo dos direitos fundamentais presentes na Constituição Federal de 1988, neste momento será explorada a situação em si que os refugiados vivem atualmente e o necessário tratamento com base na dignidade para o avanço das sociedades.

De acordo com as considerações de Barreto (2010, p. 12) o tema sobre o refúgio é tão antigo quanto a própria 
humanidade, envolvendo não somente as razões humanas, mas as considerações políticas, religiosas, sociais, culturais e de gênero, o assunto, nos últimos anos, tornou-se pauta nos grandes governos face o deslocamento de milhões de pessoas que foram obrigadas a deixar seus países de origem e buscarem abrigo e proteção internacional em outros países, muitas vezes, a milhares de quilômetros de distância entre eles.

$\mathrm{O}$ que se tem ligado à historicidade do refúgio, segundo o autor, é pautado desde a Grécia antiga, em Roma, no Egito e Mesopotâmia, sendo que naquela época, os motivos do refúgio estavam ligados às questões de religião, sempre concedidos em templos e por motivos de perseguição religiosa.

A regra era marcada para a ideia de que as pessoas que entravam nos lugares sagrados de outros países, quando insertas nesta localização, não poderiam ser atacadas pelos perseguidores, governos e exércitos, pois naquele tempo, havia o máximo respeito aos templos e divindades desses locais sagrados, tornando-se ponto estratégico para o refúgio de pessoas que buscavam o fim de violências e perseguições. Por fim, Barreto (2010, p. 12) vem considerando que nesta época os refúgios vinham beneficiando, em sua maioria, os criminosos comuns, em uma inversão de papéis que ocorre nos dias de hoje, pois naquela época, a proteção dada aqueles dissidentes políticos poderiam gerar afrontas entre nações e, consequentemente, uma guerra.

O que se tem, de acordo com o autor, é que houve uma ampliação no sistema diplomático e nas embaixadas, trazendo ao refúgio a mudança de significado, perdendo a atribuição que era dada no sentido religioso, passando a ser assunto tratado exclusivamente pelo Estado, com base na teoria da extraterritorialidade e que poderia trazer ao embaixador a prerrogativa de concessão de direitos e proteções nos limites que a embaixada ou residência permitia.

Atualmente, frisa Barreto (2010, p. 12) a teoria da extraterritorialidade não mais prevalece, sendo substituída pela teoria da jurisdição e, a partir da Revolução Francesa, é fundamentado nos ideais de liberdade e dos direitos individuais, começando a consolidar-se em aplicação ao refúgio e aos criminosos políticos, bem como a extradição de criminosos comuns. $\mathrm{O}$ autor ainda conclui: 
O avanço das relações entre Estados soberanos e a ampliação dos problemas

populacionais e de criminalidade afirmam a necessidade de cooperação internacional no combate ao crime, tornando-se inaceitável a proteção do Estado a criminosos comuns estrangeiros. A partir desses fatos, o refúgio se constitui em importante instrumento internacional de proteção ao indivíduo perseguido (BARRETO, 2011, p. 12).

Da mesma forma, Silva e Rodrigues (2012, p. 123) vem considerando que desde o princípio da humanidade existem guerras e perseguições, além da discriminação de todo o tipo. Em razão do histórico e desde aqueles tempos, há os refugiados, sendo estas pessoas vítimas de atrocidades e que poderão ser encontradas, atualmente, em todas as partes do mundo, de diversas raças, todas as cortes, religiões e que se viram obrigados a fugir de um determinado local por receio de suas vidas e famílias, além da supressão de liberdades.

Os autores na obra afirmam que os refugiados são obrigados a abandonar tudo o que possuem, como as casas, os bens, a família, identidade e o rumo a um futuro incerto em outros países, muitas vezes desconhecidos e sem nenhuma pessoa conhecida para amparar ou mesmo guiar para os melhores locais e melhores oportunidades de trabalho, por exemplo.

E assim, "em outros termos, são pessoas que fogem de condições opressivas ou perigosas existentes no seu país ou sua região e procuram abrigo em um Estado estrangeiro ou mesmo em outra região que lhe possa devolver suas condições "normais" de vida, ou seja, sua dignidade" (SILVA; RODRIGUES, 2012, p. 123).

Diante deste quadro explanado, a preocupação internacional tornou-se permanente e trazendo maior visibilidade à necessidade de haver um chamado do sistema internacional para proteção a fim de organizar-se como tal, desde a independência da América espanhola e complementando-se somente a Segunda Guerra Mundial. O quadro de maior análise da dignidade da pessoa humana foi crescente nos últimos anos desse período em face dos refugiados passarem a gradativamente tornarem-se um fenômeno hodierno e que alcançou proporções globais, em meios a essas duas grandes guerras do século XX (SILVA; RODRIGUES, 2012, p. 124). 
Vale ressaltar, como abarcaram os autores mencionados, que o termo refugiados foi aplicado originalmente a um grupo de "huguenotes" franceses. Este grupo fugiu da França para a Inglaterra após o acontecimento em 1685 da revogação do Édito de Nantes, significando, portanto, o fim da tolerância religiosa com o protestantismo.

Além desse deslocamento súbito dos franceses, a Europa no Século XX vivenciou uma onda de preocupação internacional quando os judeus foram para a Rússia se refugiar entre os anos de 1881 e 1914, após o acontecimento da revolução socialista dos bolcheviques de 1917, o do bielo-russos da URSS, bem como os judeus da Alemanha nazista, posteriormente. Silva e Rodrigues completam a informação:

(...) por outro lado, também muitos chineses abandonaram o país depois da revolução socialista liderada por Mao Tsé Tung em 1949, particularmente em direção a Hong Kong. Desde o início do regime socialista chinês, cerca de dois a três milhões de chineses estão estabelecidos em Taiwan, os quais podem ser considerados "deslocados internos" (SILVA; RODRIGUES, 2012, p. 124).

Para Mazzuoli (2014, p. 206) na mesma seara de pensamento, o tema dos refugiados sofre grande destaque no direito internacional a partir, efetivamente, da década de 1920 que foi decorrente após a Primeira Guerra e intensificando-se com a Segunda Guerra Mundial, tratando-se de uma das primeiras preocupações do direito pósguerra e que buscou inspirar todas as legislações protetivas do mundo. $\mathrm{O}$ assunto no Brasil, portanto, foi regulamentado por vários títulos legislativos internacionais ratificados pelo país e, posteriormente, disciplinando na Lei $\mathrm{n}^{\circ} 9.474$, de 22 de julho de 1997.

O amparo à dignidade dos refugiados traz importante menção quando Ramos (2018, p. 160) vem explicando que há influência recíproca entre os textos legislativos de proteção aos refugiados, como é o caso do Direito Internacional dos Refugiados que está ancorado nos demais direitos previstos na Declaração Universal de Direitos Humanos de 1948 e que procura obter, em outros países, o asilo contra a perseguição, sendo estes alvos e que precisem de auxílio no país em que buscou refúgio para continuar sem que ocorram mais violações graves dos direitos humanos. 
Sobre as origens históricas, Ramos (2018, p. 160) conclui que as raízes dos direitos e legislações sobre o refúgio possuem histórico comum, pois vieram dos pós-guerras já mencionados, mas que logo passou a serem influenciados pelos direitos humanos internacionais, com os textos já mencionados, trazendo maior atribuição de proteção e dignidade para estas pessoas, considerados como grupos vulneráveis.

Em razão disso, no artigo publicado por Cornelli, Potyra e Santos (2018, p. 134) as autoras passam elucidando que a partir das transformações globais, especialmente ligadas ao campo da tecnologia e da economia, houve uma maior evidência da separação - ou divisão - entre os países pobres e os países ricos, centrais e periféricos, que na visão das autoras, passou a gerar uma hierarquia nas relações econômicas e, consequentemente, entre os cidadãos. Suas considerações concluem:

A exclusão e discriminação dos cidadãos residentes nos países pobres e periféricos; a inacessibilidade tecnológica que apregoa segregação; a ameaça constante à dignidade; a relativização do direito à vida; a sobreposição do mercado em detrimento do humano; as
80

guerras constantes; o sonho de uma vida digna e com qualidade, forçam as pessoas a abandonarem seus lares, suas terras, provocando esse, não novo, mas intenso, fenômeno da migração e consequente crescimento de solicitações de refúgio - numa constante que se origina nos países periféricos em direção aos centrais. Todas essas condições, e seus respectivos e variados resultados, evocam respostas urgentes e ações imediatas, no intuito de salvaguardar a pessoa humana em sua personalidade internacional (CORNELLI; PORTYRA; SANTOS, 2018, p. 134).

Sobre o destaque acima, explicase e demonstra-se a existência de situações discriminatórias e que vem a ofender a dignidade da pessoa humana dos refugiados, face a necessidade de que os Estados, inclusive, no que está ligado ao cenário do Brasil e que venham a tratar da melhor forma do acolhimento dessas pessoas no país, a fim de não gerar desgaste econômico e em direitos humanos dos relacionamentos internacionais com os outros países, essas medidas devem ser eficazes contra as formas de igualdade entre em entrevistas de emprego, de atendimento público em geral, da geração de políticas públicas voltadas para o atendimento dos refugiados, entre outras medidas. 
Frisa-se Cornelli, Potyra e Santos (2018, p. 135) que as pessoas refugiadas, quando chegam em um outro país, acabam condenadas à própria sorte, pois correm o risco de estarem em algum país que não há a necessária regulamentação dos direitos humanos dos refugiados, sendo que na maioria dos países que são receptores, de acordo com as autoras, não há a discussão sobre a situação humanitária dessas pessoas, o que para eles, somente salvaguarda aqueles que estão em situação de vulnerabilidade.

As autoras concluem que essas situações ligadas a não regulamentação e o tratamento eficaz legislativo do direito dos refugiados podem gerar uma fragilização em busca de atingir $o$ atendimento dos direitos humanos ligados a todos, "ao se considerar a situação dos migrantes e refugiados, bem como a permanente agressão às suas dignidades, aos seus corpos, a supressão do reconhecimento e garantia da personalidade internacional da pessoa humana" (CORNELLI; POTYRA; SANTOS, 2018, p. 137).

$\mathrm{O}$ asilo político e o refúgio precisam, neste momento, serem demonstrados em busca de desmistificação sobre a diferença e semelhanças entre esses dois institutos.
Fernandes (2017, p. 772) portanto, abarca que o asilo político será conceituado como aquele que traz o acolhimento de um estrangeiro por parte de um Estado que não é seu, sob a fundamentação de ser uma perseguição sofrida pelo mesmo ou quando praticada em seu próprio país ou em um terceiro país. Para o autor, não há dúvidas que neste instituto, o movimento da perseguição deve ser relacionado à liberdade de manifestação de pensamento ou de expressão, e assim, ensejar o asilo político. Outra situação destacada é relacionada a dissidência política ou mesmo os crimes políticos que não configurados como crimes no direito penal comum.

Vale ressaltar, o ato de concessão de asilo político está ligado ao de soberania estatal e, no ordenamento jurídico brasileiro, quem tem competência para concessão é o Presidente da República. $\mathrm{Na}$ Constituição Federal de 1988, percebese que o asilo político está explícito como um princípio, portanto, trata-se de norma nas relações internacionais do Brasil, conforme o artigo 4, inciso $\mathrm{X}$ do texto constitucionais (BRASIL, 1988).

A natureza do asilo político, de acordo com a menção de Fernandes 
(2017, p. 772) é eminentemente territorial e que é intitulado classicamente como "asilo político territorial", e de acordo com isso, somente será concedido ao estrangeiro quando este esteja dentro do território nacional $^{4}$, ou seja, é dentro da jurisdição do Estado concedente do asilo que deve ser feito o pedido. Sobre o período de permanência do estrangeiro no território e sobre o prazo para prorrogação de permanência deverá ser determinado pelo Ministro da Justiça.

De acordo com a legislação pátria, certo também é que qualquer saída do asilado do Brasil sem a autorização do Ministério da Justiça importará em renúncia ao asilo (renúncia tácita) e impossibilitará a volta do estrangeiro na condição de asilado. Por último, nos termos constitucionais, a concessão de asilo político não impede que posteriormente seja analisado pedido de extradição do estrangeiro para um Estado requerente (conforme aqui já estudado). Basta apenas que o fato que fundamenta o pedido de extradição não envolva crimes políticos ou de opinião, já que se o objeto for este, a extradição é vedada, conforme aqui analisado pela normativa constitucional expressa no art. $5^{\circ}, \quad$ Lll, da $\quad \mathrm{CR} / 88$ (FERNANDES, 2017, p. 773).
Já no que diz respeito ao refúgio, como já explorado, estes deverão ser reconhecimentos como refugiados quando:

a) devido a fundados temores de perseguição por motivos de raça, religião, nacionalidade, grupo social ou opiniões políticas, encontre-se fora de seu país de nacionalidade e não possa ou não queira acolher-se à proteção de tal país;

b) não tendo nacionalidade $\mathrm{e}$ estando fora do país onde antes teve sua residência habitual, não possa ou não queira regressar a ele, em função das circunstâncias descritas no item anterior; c) devido à grave e generalizada violação de direitos humanos, é obrigado a deixar seu país de nacionalidade para buscar refúgio em outro país (FERNANDES, 2017, p. 773).

Além de serem extensivos aos cônjuges, aos ascendentes e descendentes, como os demais membros da família. Assim, os refugiados gozarão dos direitos e estão sujeitos aos deveres dos estrangeiros no Brasil, de acordo com o disposto na Lei $n^{\circ}$ 9.474/97, na Convenção sobre o Estatuto dos Refugiados de 1951 e no Protocolo sobre o Estatuto dos Refugiados de 1967, cabendo-lhes a obrigação de acatar as

\footnotetext{
${ }^{4} \mathrm{O}$ autor explica que o estrangeiro, mesmo quando estiver no território que pretende obter o asilo político, poderá solicitar.
} 
leis, os regulamentos e as providências que se destinam à manutenção da ordem pública.

O refugiado, neste sentido, de acordo com Fernandes (2017, p. 763) terá o direito de obter a cédula de identidade comprobatória da condição jurídica, carteira de trabalho e o documento de viagem.

O procedimento, ressalta Sarlet (2018, p. 765) deve ser solicitado a qualquer autoridade migratória que estiver na fronteira do Brasil, proporcionando as informações necessárias para proceder com a concessão. Essa concessão de refúgio deve ser operada através da via administrativa e parte da decisão do Poder Executivo, perante um Comitê Nacional para os Refugiados (CONARE), sendo este um órgão vinculado ao Ministério da Justiça e que deve analisar os pedidos e decidir sobre as solicitações de refúgio, inclusive sobre os casos de cessação.

Ressalta-se, a concessão do refúgio vem assegurando a pessoa $o$ respectivo status e proteção nos termos da lei interna e dos diplomas internacionais que são aplicados no Brasil, sendo que uma das principais consequências é o reconhecimento da condição de refugiado, conforme o artigo 33 da Lei $\mathrm{n}^{\circ} 9.474$ e que resultado no seguimento de qualquer pedido de extradição que seja baseado nos fatos que fundamentaram a concessão desse pedido (SARLET, 2018, p. 765).

Após este tratamento da diferença entre asilo e refúgio, sucintamente será explorado o que são os grupos minoritários ou vulneráveis, em busca de trazer também o ensinamento em razão da proteção contra discursos de ódio, discriminação no mercado de trabalho e outras afrontas à dignidade da pessoa humana.

Neste sentido, Carmo (2016, p. 206) inicia seu desenvolvimento frisando sobre a ideia de grupo minoritário como aquele que tem sido debatido e compreendido de diversas maneiras por pesquisadores de várias áreas, não somente os do Direito.

Mais adiante, de acordo com a ampla pesquisa, verifica-se que Acselrad (2006, p. 2) em sua obra configura o conceito de minorias como aquelas que partem de uma perspectiva iluminista, com a acepção de que a minoria não parece ter um termo adequado para representação de grupos que sejam "menos poderosos", mesmo quando, aparentemente para o autor, contrariem o 
ideal de união universal que o próprio movimento iluminista abarcou.

$\mathrm{O}$ autor conclui:

(...) como é possível fazer uma leitura da noção de minoria a partir do pensamento iluminista? Como defender a noção de minorias étnicas, raciais, de gênero, etárias e outras mais a partir de uma perspectiva universal, de uma concepção de homem que considere a semelhança (entre todos) mais importante do que a diferença (entre os grupos). A diferença separa. A semelhança permite inclusive, mas não primordialmente, perceber $\mathrm{o}$ estabelecimento de uma diferença, desde que esta nunca se sobreponha àquela. $\mathrm{O}$ direito à diferença só passa a ser a principal bandeira a partir do momento em que se acredita mais na identidade (intragrupos) do que na semelhança (entre os grupos). O risco é cair-se numa querela identitária, num particularismo infindo, num discurso relativista e sempre parcial (ACSERALD, 2006, p. 2).

O autor coloca, portanto, sua posição, elucidando que entende a minoria não como a questão de classe ou grupo, não implicando em pertencer a uma determinada entidade ou instituição, sendo que não dependerá, portanto, de cor de pele ou lugar de origem.

Assim, as acepções mudam quando não se trata de "maiorias" afirmando então, depende da "massa", sendo que são configurados como aquela massa que passa a ser todas as pessoas que não são valorizadas em si mesmas por razões especiais, mas se sente como todo mundo, entretanto, não se angustia e sente-se à vontade de ser idêntico aos demais. Já a minoria, para o autor, é todo aquele que passa a se separar da multidão de homens iguais, "por razão essencialmente individuais, não sendo em absoluto forçado a tal" (ASCERALD, 2006, p. 2).

Sendo assim, as noções de massa e de minoria são consideradas como fatos psicológicos, como posturas opostas diante do mundo e da vida, e não como o simples pertencimento a grupos minoritários ou majoritários. A minoria (...) é uma forma de vida nobre, superior, que implica em exigir sempre mais de si mesmo. Não há, pois, uma classe ou grupo minoritário, uma vez que a coincidência com outros que formam a minoria é secundária, posterior a se haver cada qual singularizado e é, portanto, em boa parte uma coincidência em não coincidir (ASCERALD, 2006, p. 2).

Mais adiante, de uma forma diferente de abordagem de Acselrad, Rifiotis (2006, p. 8) vaticina se tratar da compreensão de minorias como aqueles grupos que poderiam, em circunstâncias diferenciadas, correr o risco de ter 
destruída a própria identidade, sendo vítimas de processos de controle de homogeneização, é o que poderá ocorrer com os refugiados, nestes casos em análise.

O discurso sobre a violência não compreende apenas a fala, nem é consciente para quem o enuncia; ele também é o nãodito ou o silenciado, um conjunto de enunciados, práticas e falas, que garantem a circulação das imagens sobre a própria violência. $\mathrm{O}$ discurso sobre a violência é o leito de um grande rio, cujas marcas de ambiguidade estão presentes mesmo no seu estudo (...) Cada minoria, grupo ou segmento social poderia, sob determinadas circunstâncias concretas, colocar em prática formas específicas de violência para garantir a sua identidade. No limite lógico da homologia entre

"sociedades primitivas" e minorias sociais, há consequências extremamente complexas do ponto de vista ético e que devem ser consideradas: quais as implicações de considerarmos que os sujeitos envolvidos em situação de violência estariam valendo-se de um instrumento para a construção ou garantia de manutenção da sua subjetividade, ou seja, marcando a fronteira com o que consideram exterior? (RIFIOTIS, 2006, p. 8)

O questionamento do destaque anterior é o que busca o autor Rifiotis (2006, p. 8) em seu estudo antropológico

\section{5}

que não cabe neste trabalho explaná-lo por inteiro. Mais adiante, já outra autora, como Séguin (2002, p. 14), em sua obra, relaciona-se a partir de uma perspectiva jurídica, considerando que as minorias também podem ser chamadas de grupos vulneráveis, sendo aqueles descritos como aquelas pessoas que são unidas por características em comum, embora não estabeleçam uma proximidade de corpos em si.

Para a autora, o que encontra relação é que há estreitamento das relações de afeto no que tange àqueles das minorias e dos grupos vulneráveis, sempre em razão do que passam cotidianamente, como o poder que lhes é tirado, o processo que as maiorias causam por dominar as minorias, a violência sofrida e o medo recorrente, bem como a marginalização social (SÉGUIN, 2002, p. 14).

Nesta seara, Carmo conclui com os seus estudos:

(...) todos os autores indicam que minorias e grupos vulneráveis originam-se em relações de assimetria social (econômica, educacional, cultural etc). Nessa perspectiva, minoria pode ser definida a partir de uma particularização de um grupo, já que a maioria se define por um agrupamento generalizado, ou seja, por um processo de generalização 
baseado na indeterminação de traços, os quais indicam um padrão de suposta normalidade, considerada majoritária em relação ao outro que destoar dele. A vulnerabilidade advém, pois, de pressões desse suposto padrão de normalidade, que pressiona tudo e todos que possam ser considerados diferentes. A violência, por sua vez, tanto pode ser física quanto simbólica, originária dessa pressão, que, muitas vezes, na forma de preconceito e rejeição, marginaliza e discrimina o diferente (CARMO, 2016, p. 206).

Envolvido nesta seara que o discurso de ódio está presente, atacando as minorias, podendo estas serem consideradas como os refugiados, inclusive, em análise quando se trata do oferecimento e oferta no mercado de trabalho, tema a ser analisado no próximo capítulo.

Sob a vida cotidiana dessas pessoas, poderão passar por situações desconfortáveis, até envolvendo atitudes de violência, discussões sobre a legalidade, legitimidade e as formas de expressão que formam um grupo vulnerável ou mesmo as minorias, é por este motivos que busca-se atrelar a estas pessoas refugiadas os direitos fundamentais e a dignidade da pessoa humana para melhor atendimento no país de acolhimento, transformando-se em
86 uma sociedade próspera e livre de preconceitos, racismos e discriminações.

\section{GÊNERO: Dignidade humana}

Gênero é uma categoria complexa e amplamente discutida na contemporaneidade, é um termo cunhado na acadêmica e que extrapola os âmbitos dessa esfera para se apresentar em várias instâncias sociais, constituindo-se um termo amplamente refletido, discutido e utilizado. Dias (1992), argumenta que os estudos de gênero surgem como uma possiblidade de reconstrução dos discursos históricos instituídos pelo sistema de dominação cultural, esses estudos expõe a crise nas relações de gênero e lançam uma esperança de transformação nas relações desiguais entre os gêneros. Os estudos feministas propõem encontrar um caminho que elabore uma história de gênero, que redescubra e intérprete a história das mulheres, e as represente em seus processos sociais e históricos. Dessa forma, desmistifica não somente as relações de gênero, mas também conceitos já reproduzidos e herdados há séculos tais como: família, cidadania e 
sociabilidades, que definem a natureza feminina.

As interseções dos estudos de gênero expandem as formas de conceber os conceitos duais como: público e privado, ideologicamente construídos pela história tradicional, que impõe à mulher menor participação no espaço público, e ainda contribui para a mudança e transformações nessas concepções tradicionais.

Scott (1990) discute como a categoria de gênero é interpretada no sentido de modificar a história das mulheres, ou de reafirmar a história tradicional que neutraliza a participação das mulheres nas histórias oficiais. Scott faz essa análise a partir da forma metodológica que diversos autores formulam e empregam seus conceitos sobre gênero em suas teorias. Dessa perspectiva Scott (1990), afirma que o termo gênero não conseguiu ser aprisionado nem mesmo pelas Academias. Argumenta que as feministas iniciaram o uso de gênero para se referir "à organização social da relação entre os sexos". Para a autora foram as feministas americanas as precursoras do termo, para repelir o determinismo biológico que fixava o uso dos termos "sexo" e "diferença sexual", a intenção era que o termo gênero pudesse mostrar que, não se pode compreender a mulher e o homem em estudos que polarizam esses sexos. Scott (1990) acrescenta:

[...] nosso objetivo é compreender a importância dos sexos, isto é, dos grupos de gênero no passado histórico. Nosso objetivo é descobrir o leque de papeis e simbolismos sexuais nas diferentes sociedades e períodos, é encontrar qual era o seu sentido e como eles funcionavam para manter a ordem social ou para mudá-la (SCOTT, 1990, p. 72).

Dessa forma, a utilização do termo gênero foi sustentada como importante para a quebra de paradigmas disciplinares, e para propor um exame crítico dos trabalhos científicos já até então produzidos. Isso levaria a ruptura das noções tradicionais, a fim de dar visibilidade às experiências pessoais e subjetivas das atividades políticas e públicas das mulheres. De acordo Scott (1990, p. 72) "não é demais dizer ainda que as tentativas iniciais tenham sido hesitantes, uma tal metodologia implica não somente uma nova história de mulheres, mas também uma nova história".

A autora afirma que, gênero repele a afirmação biológica que explicam e reafirmam as diversas formas de subordinação da mulher como sexo 
mais frágil e naturalmente maternal, enquanto os homens são naturalmente fortes. Ao contrário, gênero torna-se uma forma de explicar os papéis sociais destinados aos homens e mulheres e como isso se estrutura nas "construções culturais". Scott (1990, p 74) esclarece, [...] "trata-se de uma forma de se referir às origens exclusivamente sociais das identidades subjetivas de homens e mulheres".

Scott (1990), afirma que a preocupação teórica com o gênero como categoria de análise iniciou no século $\mathrm{XX}$, e isso refletiu na dificuldade das feministas em incorporar esse termo no vocabulário das escolas teóricas. As feministas utilizaram gênero para estabelecer a definição das desigualdades entre homens e mulheres. Scott, sobre isso acrescenta:

[...] no espaço aberto por esse debate, posicionados ao lado da crítica da ciência desenvolvida pelas humanidades e da crítica do empirismo e do humanismo desenvolvidos pelos/as pósestruturalistas, as feminista não somente começaram a encontrar uma voz teórica própria; elas também encontraram aliados/as acadêmicos/as e políticos/as. É dentro desse espaço que nós devemos articular gênero como uma categoria de análise (SCOTT, 1990, p. 85).
Ela explica que, os métodos de análise de gênero devem ser examinados, e que gênero é composto de diversas partes conectadas e inter-relacionadas, gênero é um conjunto de elementos que constitui as relações sociais baseadas e nas diferenças que ocorre entre os sexos. Scott (1990) afirma, o gênero é um elemento que faz parte do que constitui as relações sociais estabelecidas nas diferenças entre os sexos, e é uma forma primária de dar sentido as relações de poder. Para a autora o desafio da nova pesquisa é dirimir as definições já estabelecidas e rijas das análises que fixam a separação entre masculino feminino, e incluir na análise histórica conjunta dos sexos, a análise das concepções políticas, da estrutura de poder, e da estrutura social da sociedade.

Assim como Scott, Pedro (2005) argumenta que "gênero é a organização social da diferença sexual", e ainda que gênero, "é um saber que estabelece significados para as diferenças corporais". Discute ainda que, o uso da categoria de gênero como análise, propicia aos pesquisadores (as) e historiadores (as), apreender as tensões e acontecimentos produtores de gênero entre homens e mulheres, entre mulheres e mulheres. Essa definição abriu luz para 
estudos sobre as relações de poder e conflitos que ocorrem entre pessoa do mesmo sexo.

Utilizar gênero como categoria de análise, ilumina a forma de compreender as relações sociais estruturadas nas vivências nos espaços de sociabilidades humanas (trabalho, escolas, família, política, meios de comunicação etc) para questionar as "verdades" tradicionais já solidificadas, e dar visibilidade nas diferenças e questionar a subalternidades e relações de poder que geram exclusão para as mulheres, em diversos espaços, como o espaço político por exemplo.

Nesse sentido para Scott (2012) gênero é um lugar de luta e questionamentos, que permite a contestação política de tudo que está ligado a rigidez positivista que determina a fixação dos papéis atribuídos a todos. Assim, gênero se torna uma categoria de análise útil para o exercício da criticidade, a fim de: entender, contestar, resistir e discutir as relações desiguais, as relações de poder, as normatizações, as transgressões, a cultura, as relações sociais e a política na atualidade.

Por sua vez Okin (2008) afirma que a teoria de gênero, tem muita relevância na análise dessas relações entre homens e mulheres, e gênero permite entender e mudar as práticas tradicionais de separação do público e do privado, e que práticas fundamentadas no gênero sejam mais disseminadas e melhoradas para que as mulheres tenham chances iguais aos homens nas esferas do trabalho e da política e ainda, se beneficiem da privacidade. É preciso sob a perspectiva de gênero, objetivar uma sociedade igualitária que as responsabilidades, papéis e tarefas da vida doméstica sejam dívidas por igual entre homens e mulheres.

\section{A abordagem dos direitos humanos e os refugiados em São Paulo}

Em forma de acolher os refugiados no Brasil, principalmente no que se trata a cidade de São Paulo, existe o Instituto de Reintegração do Refugiado, conhecido como ADUS, é uma Organização da Sociedade Civil de Interesse Público que vem atuando junto aos refugiados e estrangeiros que são vítimas de migrações forçadas e que estão localizados na cidade de São Paulo, com o intuito de reduzir os obstáculos que surgem em busca de efetivar uma 
integração e reintegração na sociedade em geral (ADUS, 2019).

A missão da instituição é oferecer diversos cursos, como aulas de qualificação profissional, aulas de língua portuguesa, além da assistência com apoio psicológico, inserção no mercado de trabalho e a busca por instrução na preparação em empreendedorismo e ações culturais. Desta forma, afirmam "atuar em parceria com solicitantes de refúgio, refugiados e pessoas em situação análoga ao refúgio para reintegração à sociedade buscando sua valorização e inserção social, econômica e social" (ADUS, 2019).

Procuram "superar os obstáculos para reintegração dos refugiados de forma que eles tenham autonomia e as ferramentas necessárias para que possam buscar sua própria inserção na sociedade". (ADUS, 2019) E como valores, afirmam se tratar do empoderamento, do compromisso, humanismo, participação, igualdade, transparência e ética.

O Instituto de Reintegração do Refugiado também trouxe a criação de escola de idiomas, conhecido como "projeto conectadus", em que os refugiados passam a ministrar aulas de inglês, francês e árabe, além de um projeto de gastronomia denominado "sabores \& lembranças" e que realizam workshops de gastronomia e serviço catering (ADUS, 2019).

A estimativa de atendimento da instituição é de quinhentas pessoas no mês, sendo que os refugiados são provenientes de mais de cinquenta nacionalidades, sobretudo os países da Síria, Congo, Palestina, Angola e Colômbia.

Outro organismo dentro da cidade de São Paulo está o Cáritas Brasileira, criando o Centro de Acolhida a Refugiados, juntamente com a atuação da Agência da Organização das Nações Unidas para Refugiados e em colaboração com o Ministério da Justiça, o Cáritas Brasileiras é uma das poucas entidades, segundo as informações do site consultado, que prestam serviços de acolhimento e integração aos refugiados no Brasil (CÁRITAS BRASILEIRA, 2019).

Além disso, mais adiante será explorado, a iniciativa da Prefeitura de São Paulo em criar o Conselho Municipal do Imigrante passou a ser reconhecido como um dos projetos mais integradores pela Organização das Nações Unidas, como será visto neste capítulo. 
A situação dos refugiados na cidade de São Paulo

$\mathrm{Na}$ cidade de São Paulo, conforme informações das matérias recolhidas, no que se refere Leite e Sousa (2018) o número de refugiados no último ano aumentou, tanto na Grande São Paulo como nas cidades do interior do Estado.

As informações são retiradas segundo o relatório divulgado pela Organização das Nações Unidas no sentido de que São Paulo está entre as cidades do Brasil que mais vem recebendo imigrantes, de forma que é a principal, neste momento, demonstrando que no últimos anos, cidades do interior e da Grande São Paulo têm o maior registro de número de estrangeiros acolhidos (LEITE; SOUSA, 2018).

Segundo as autoras, o movimento de refugiados aumentou no interior paulista, fora das grandes cidades, como demonstra-se, os estrangeiros encontram mais acolhimento e qualidade de vida, bem como as oportunidades de trabalho aumentam, principalmente nos empregos ligados ao setor da indústria e serviços (LEITE; SOUSA, 2018).
Em 2000, Leite e Sousa (2018) afirmam que além da cidade de São Paulo, somente quatro cidades no Estado tinham como registros de moradores com pedidos de refúgio aceitos, porém, no ano de 2016, o número mudou para trinta e sete cidades. Portanto, em dezesseis anos o número das solicitações aumentou sete vezes, já que em 2000 eram cinquenta e oito estrangeiros aceitos como refugiados e em 2016 subiu para quatrocentos e quarenta e oito. Concluem as autoras que em dezesseis anos os sírios foram os refugiados que marcaram o maior número em razão do aumento dos pedidos de refúgio, sendo ao todo mil e trinta deles.

A consequência do aumento de refugiados no Brasil e, consequentemente em São Paulo, de acordo com a matéria, está ligada ao fechamento dos países do norte cada vez mais negando a condição dos refugiados em seus países, tendência que cresce cada vez face os posicionamentos dos presidentes do Estados Unidos, Canadá e os países da Europa em geral, tendendo os do sul a recepcionarem mais essa migração e, dessa forma, o Brasil tem sido o principal local para a migração, ampliando a diversificação das 


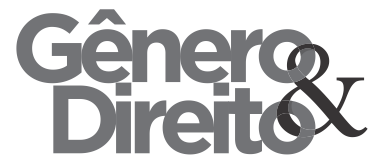

Periódico do Núcleo de Estudos e Pesquisas sobre Gênero e Direito

Centro de Ciências Jurídicas - Universidade Federal da Paraíba V. 8 - No 03 - Ano 2019

ISSN | 2179-7137 | http://periodicos.ufpb.br/ojs2/index.php/ged/index comunidades de refugiados no país e em São Paulo.

Os dados foram retirados do projeto temático do observatório das migrações em São Paulo, com a colaboração da UNICAMP, NEPO, CEPAGRI, IFCH, UFABC, Fundação Carlos Chagas, Museu do Café e Museu da Imigração, colaborando com o objetivo principal de conhecer a analisar as transformações causadas pelos efeitos migratórios no Brasil no Estado de São Paulo a partir da diversificação das modalidades migratórias (NEPO, 2019).

De acordo com o Banco Interativo Observatório das Migrações em São Paulo, os imigrantes internacionais que possuem condição de refúgio e que foram registrados pelo Sistema Nacional de Cadastros e Registros de Estrangeiros (SINCRE) entre os anos de 2000 a 2016 no Estado de São Paulo tem como sírios os dados 1.030; as pessoas da República Democrático do Congo em 318; originários da Colômbia tem-se os dados em 241; de Mali há 91 pessoas; do Iraque, 90; enquanto na Angola e Líbano por volta de oitenta; os advindos da República do Congo em 84; de Serra Leoa, 95 e de outros países há o índice de imigrantes internacionais em 491 deles (UNICAMP, 2016).

TABELA 1 - IMIGRANTES INTERNACIONAIS COM A CONDIÇÃO DE REFÚGIO REGISTRADO NO SISTEMA NACIONAL DE CADASTROS E REGISTROS DE ESTRANGEIROS (SINCRE) ENTRE OS ANOS DE 2000-2016 E RESIDENTES NO ESTADO DE SÃO PAULO, POR PAÍS DE NASCIMENTO 


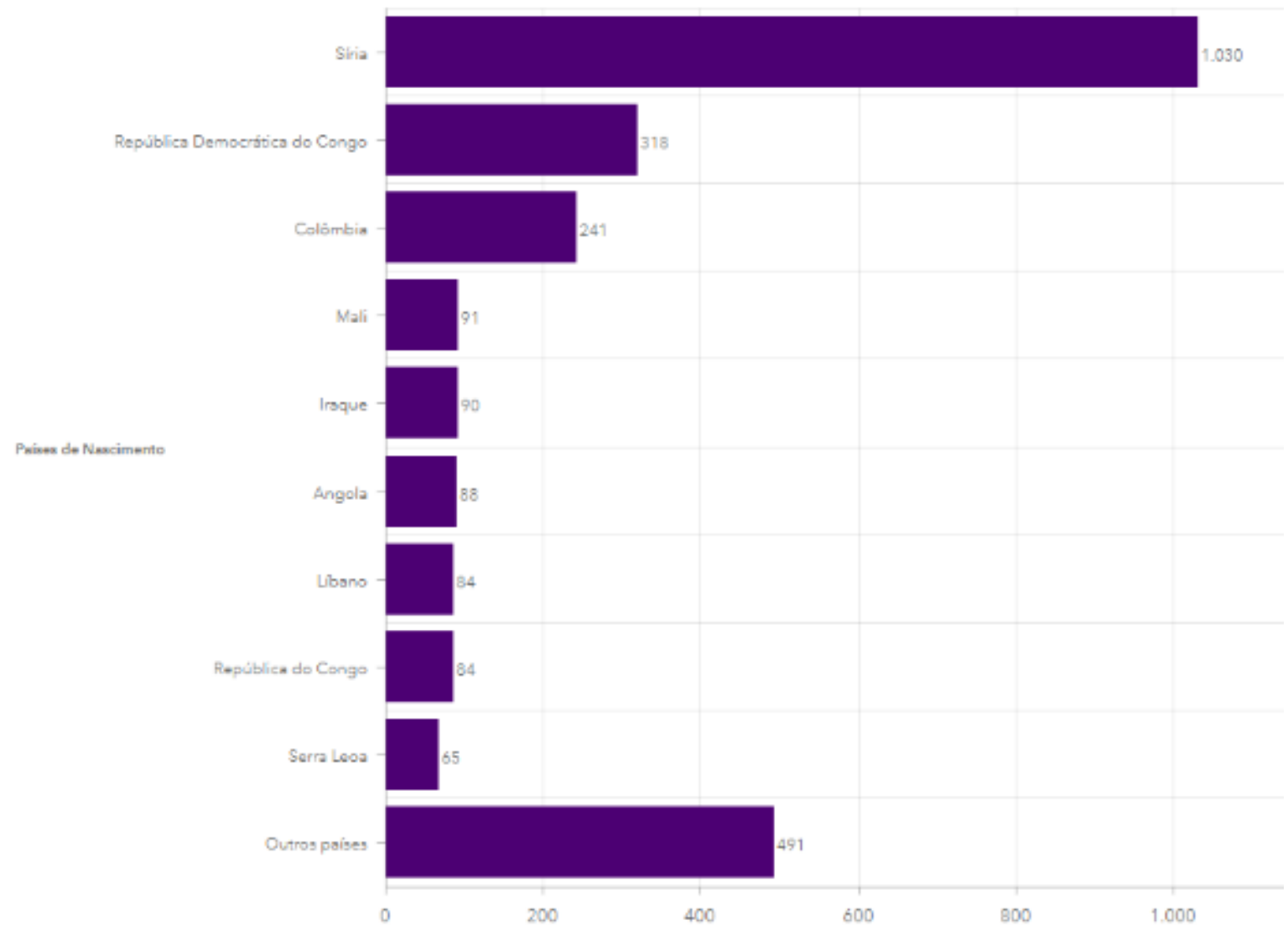

FONTE: UNICAMP. Banco Interativo Observatório das Migrações em São Paulo - Imigrantes internacionais com a condição de refúgio registrados no Sistema Nacional de Cadastros e Registros de Estrangeiros (SINCRE), entre 2000-2016, no Estado de São Paulo. Publicado em 2016. Disponível em https://unicamparcgis.maps.arcgis.com/apps/opsdashboard/index.html\#/330f0fd0555847daabd247d560 cbeb4c. Acesso em 14 mai. 2019.

Outro projeto interessante é o Projeto Missão de Paz, instituição filantrópica que possui o objetivo de apoiar e acolher os imigrantes e refugiados no Brasil desde 1939 iniciado pelos missionários de São Carlos. A Congregação, a partir dos dados retirados do site, é uma comunidade internacional de religiosos formada por trinta e quatro países dos cinco continentes, acompanhando os migrantes de diversas culturas, crenças e etnias.

Com dados acompanhados do CONARE, o relatório de refugiados em números no Brasil tem a totalidade, até o ano de 2017, em 10.145 refugiados de diversas nacionalidades acolhidos pelo 
Brasil, desses, apenas 5.134 continuam com o registro ativo no país, dentre eles, $52 \%$ moram em São Paulo, $17 \%$ no Rio de Janeiro e $8 \%$ no Paraná (ACNUR, 2017).

O ano de 2017 foi o maior em número de pedidos de refúgio, desconsiderando a chegada dos venezuelanos e dos haitianos. Foram 13.639 pedidos no ano passado, 6.287 em 2016, 13.383 em 2015 e 11.405 em 2014.No total, 33.866 pessoas solicitaram o reconhecimento da condição de refugiado no Brasil em 2017. Os venezuelanos representam mais da metade dos pedidos realizados, com 17.865 solicitações. $\mathrm{Na}$ sequência estão os cubanos (2.373), os haitianos (2.362) e os angolanos (2.036). Os estados com mais pedidos de refúgio são Roraima (15.955), São Paulo (9.591) e Amazonas (2.864), segundo dados da Polícia Federal (ACNUR, 2017).

De acordo com Jubilut (2012, p.

33) São Paulo, juntamente com o Rio de Janeiro, de acordo com os dados mais atuais demonstrados no capítulo, é o núcleo mais antigo que possui em atendimento aos refugiados no Brasil, demonstrando que na cidade de São Paulo a acolhida aos solicitantes de refúgio e refugiados ocorre com as instituições, já mencionadas, Cáritas Arquidiocesana de São Paulo e o Alto
Comissariado das Nações Unidas para Refugiados, encarregado este último desde o ano de 1950 para os cuidados com os refugiados e a proteção da população vulnerável neste sentido, englobando os refugiados, os solicitantes de refúgio e pessoas em situações análogas, como ocorrem com os deslocados internos.

Desde o ano de 1994, Jubilut (2012, p. 33) assevera que existe o convênio com o Centro de Acolhida para Refugiados, assistente e orientador no auxílio à população refugiada que busca recomeçar as vidas e resgatar a dignidade no Brasil.

Trata-se de uma população vitimada em seus direitos mais fundamentais, uma vez que são refugiadas as pessoas que têm bem-fundado temor de perseguição, em função de sua raça, religião, nacionalidade, opinião política ou pertencimento a um grupo social; que estejam fora de seu Estado de origem e/ou residência habitual; e que sejam carecedores e merecedores de proteção internacional. Ou seja, são pessoas que não podem contar com a proteção de seus Estados prescindindo do auxílio da comunidade internacional e contando com a solidariedade dos demais Estados e sociedades civis (JUBILUT, 2012, p. 33-34). 
A solidariedade nas cidades, e em razão especial a análise na cidade de São Paulo, é essencial para que a população venha a se sentir segura e resgate a dignidade antes perdida em razão do país de origem, face que serão os Estados que irão assegurar a efetividade da proteção aos direitos fundamentais, concedendo o status de refugiados nos territórios, uma vez que os Estados são esferas primárias de realização de Direitos Humanos (JUBILUT, 2012, p. 34).

Deve-se apostar no amparo à sociedade de refugiados em São Paulo não somente com as ações governamentais, mas também "por outro lado, podendo a sociedade civil ser vista como a manifestação concreta dos valores de uma determinada sociedade por exemplo, pelo trabalho das Organizações Não - Governamentais (ONGs) -, ela vem a ser o principal meio de integração dos refugiados a esta" (JUBILUT, 2012, p. 34).

\section{Conselho Municipal Do Imigrante}

O Conselho Municipal do Imigrante, a partir da análise do Regimento Interno, possui como natureza e finalidade como sendo um órgão consultivo que deve ser vinculado ao Departamento de Políticas para Imigrantes e Promoção do Trabalho Decente da Secreta Municipal de Direitos Humanos e Cidadania de São Paulo, contando com a Lei Municipal $\mathrm{n}^{\circ}$ 16.478, de 8 de julho de 2016 que veio instituindo a Política Municipal para a População Imigrante, também com o Decreto Municipal no 57.5333, de 15 de dezembro de 2016.

Com a verificação, o Conselho possui diretrizes e princípios que buscam seguir no desenvolver das atividades, traçados no Regulamento Interno:

I - igualdade de direitos e de oportunidades, observadas as necessidades específicas dos imigrantes; II - promoção da regularização da situação da população imigrante; III universalidade, indivisibilidade e interdependência dos direitos humanos dos imigrantes; IV combate à xenofobia, ao racismo, ao preconceito e a quaisquer formas de discriminação; V - promoção de direitos sociais dos imigrantes, por meio do acesso universalizado aos serviços públicos, nos termos da legislação municipal; VI fomento à convivência familiar e comunitária (SÃO PAULO, 2018, p. 1).

Mais adiante, no artigo $3^{\circ}$ traçase as competências que o Conselho Municipal deve seguir, ou seja, deverá participar de formulação, 
implementação, monitoramento e da avaliação da Política Municipal para a população imigrante de São Paulo, bem como verificar outras políticas que poderão ser desenvolvidas pelo poder público; deverá defender e promover os direitos dos imigrantes, fomentando a inclusão social, cultural, política e econômica; deverá trabalhar de forma articulada com os Conselhos e imigrantes eleitos para o Conselho Municipal; pronunciar-se em razão de matérias que lhes são submetidas; fomentar e estimular o associativismo e a participação políticas dos imigrantes, e por fim, convocar e realizar, a cada dois anos, as Conferências Municipais de Políticas para Imigrantes e Audiências e Consultas Públicas que venham a envolver e integrar a população imigrante (SÃO PAULO, 2018, p. 2-3).

A Organização das Nações Unidas veio elogiando a iniciativa da cidade de São Paulo para integração dos refugiados e migrantes com a eficiente atuação do Conselho Municipal do Imigrante, dando a chance a estes, como vistos nos artigos estudados, de participação ativa politicamente das pessoas que vivem na cidade de São Paulo. Da mesma forma, houve a celebração da criação do organismo internacional do Centro de Integração e Cidadania do Imigrante que traz assistência jurídica e capacitação dos estrangeiros (ONU, 2018).

\section{E mais:}

Outra inciativa elogiada pelo ACNUR é o Centro de Integração e Cidadania do Imigrante, também conhecido pela sigla CIC do Imigrante. O projeto do governo estadual é uma resposta a necessidades de assistência, incluindo para vítimas de tráfico de pessoas e trabalho escravo. A instituição conta com um espaço público que oferece cursos gratuitos de capacitação profissional, como as escolas de estamparia e panificação. No local, também são mantidos serviços de auxílio jurídico e orientação migratória. O CIC disponibiliza ainda acesso à internet, bem como outros serviços para ajudar os refugiados e migrantes que buscam informação (ONU, 2018).

Em consonância com o Conselho Municipal dos Imigrantes, portanto, surge a Coordenação de Políticas para Imigrantes e Promoção do Trabalho Decente que acarreta na necessidade de criação de um objetivo de articular as políticas públicas migratórias de forma que traga a promoção do trabalho das pessoas imigrantes e refugiadas no Brasil.

Insta mencionar as iniciativas de acordos que o Conselho Municipal dos 
Imigrantes vem fechando com as instituições, como é o caso do acordo de cooperação com o Bando do Brasil S/A assinado em 22 de abril de 2014 que traz a colaboração na bancarização de imigrantes que são residentes no município de São Paulo ${ }^{5}$, bem como a promoção da cultura de respeito aos direitos humanos dos imigrantes; a realização de divulgação sobre os serviços prestados aos imigrantes; a iniciativa de regularização migratória; garantia de maior segurança e inserção social dos imigrantes através da bancarização e a elaboração de um Plano de Trabalho com ações, cronograma e áreas responsáveis, possibilitando a inserção do refugiado no mercado de trabalho. Da mesma forma foi promovido anteriormente com a Caixa Econômica Federal em 04 de outubro de $2013^{6}$.

Com a colaboração do Conselho Municipal dos Imigrantes, é possível perceber os avanços que os refugiados tiveram no mercado de trabalho na cidade de São Paulo, em face da matéria publicada pela Organização das Nações

${ }^{5} \mathrm{Cf}$.

https://www.prefeitura.sp.gov.br/cidade/secretar ias/upload/direitos_humanos/Acordo\%20Banco \%20do\%20Brasil.pdf. Acesso em 14 mai. 2019.
Unidas no Brasil, que veio trazendo que a trajetória de exemplos de pessoas que conseguiram apresentar os projetos de empregabilidade ao chegar no Brasil, com a capacitação de refugiados e migrantes que também possuem o animus de recomeçar a vida no Brasil (ONU, 2019).

Sobre a situação da Venezuela atualmente, tem-se a verificação de dados que a cidade de São Paulo lidera no processo de acolhimento de venezuelanos, contabilizando mais de três mil interiorizados em todo o país, a cidade é reconhecida internacionalmente por acolhimento de refugiados $\mathrm{e}$ imigrantes, sendo o lar de mais de quinhentos venezuelanos que chegaram por meio de parceria efetuada entre o município com o governo federal e as agências da ONU Brasil (ONU, 2019).

\section{Conclusão}

O trabalho teve seu desenvolvimento pautado na dignidade da pessoa humana, conceituada como aquela atribuição inerente ao ser

\footnotetext{
${ }^{6} \mathrm{Cf}$.

https://www.prefeitura.sp.gov.br/cidade/secretar ias/upload/direitos_humanos/Acordo\%20SMD HC\%20e\%20CAIXA.pdf. Acesso em 14 mai. 2019.
} 
humano, o homem já nasce com ela, devendo as determinações as quais o Estado Democrático está inserido, mantê-la e conservá-la. Porém, em determinados momentos da história é possível verificar guerras, estados autoritários e perseguidores, dentre diversas outras situações que acabam por infringir essa dignidade do homem, momento este, que se busca o refúgio do país que o persegue, em busca de restabelecer, às vezes, toda um núcleo familiar no país.

A análise procurou trazer o que o Brasil possui como arsenal para proteção dos refugiados, mas também com o escopo voltado para a cidade de São Paulo, um dos maiores centros de recebimento de refugiados no país, contando com aqueles de origem síria, da República Democrática do Congo, da Colômbia, outros países e atualmente com o crescimento de acolhida de venezuelanos na metrópole.

As políticas públicas de atendimentos nacionais aos refugiados buscam de forma incisiva trazer a inclusão dessas pessoas na sociedade, pautando-se no que também é importante, a fim de conscientizar a população brasileira da inclusão e fim do tratamento discriminatória dessas pessoas.

O tratamento aos refugiados na perspectiva de gênero deve ser igualitário para homens e mulheres, deve primar pela igualdade entre os gêneros, do ponto de vista social (desenvolvimento). Dessa perspectiva, o desenvolvimento deve se voltar para além das questões econômicas, priorizando também as questões que envolvem a desigualdade de gênero, e objetivando provocar oportunidades igualitárias e a afirmação dos direitos e igualdade de participação democrática para homens e mulheres em todos os espaços.

O desenvolvimento na perspectiva de gênero segundo Scott (1990) surge como uma concepção da visão feminista de mundo, e implica em uma nova visão de desenvolvimento que considera a ruptura com antigas concepções. Essa nova visão, tem como um dos seus objetivos contribuir para a construção de uma nova resignificação da história subjetiva e social da sociedade, da cultura e da política das mulheres e para as mulheres. Essa perspectiva de acordo Scott (1990), reconhece a diversidade de gêneros e a existência das mulheres e dos homens, 
como um princípio essencial para a construção de uma sociedade democrática e mais igualitária.

Dessa forma, demonstrou-se que os centros de acolhida como são com o Instituto de Reintegração do Refugiado e o Cáritas Brasileiras, na atuação na cidade de São Paulo, possuem diversas atividades como o ensino da língua portuguesa e cursos profissionalizantes, em forma de inserção dessas pessoas no mercado de trabalho, bem como os métodos de empreendedorismo e a inclusão no sentido de que os refugiados também dão aulas repassando o ensino do uso da língua estrangeira, a cultura e o que podem influenciar para trazer novamente a dignidade da pessoa humana à tona.

A importância analisada do Conselho Nacional do Imigrante em São Paulo é a busca pelo atendimento de diretrizes em razão da igualdade de direitos e oportunidades; a promoção da regularização da situação dessas pessoas no país; o combate à xenofobia e a promoção dos direitos sociais dos imigrantes. Elogiado pela ONU, o Conselho traz o objetivo de articular diversas políticas públicas para promoção do trabalho dessas pessoas.
Dessa forma, com o auxílio de toda a composição constitucional de direitos fundamentais que o Brasil possui hoje, existem diversas políticas de inclusão de forma digna do refugiado na sociedade brasileira, principalmente em análise à de São Paulo, de maneira a demonstrar a preocupação de atendimento e determinação dos direitos sociais às pessoas carentes e refugiadas, que vêm ao Brasil em busca de novas oportunidades, inclusive, reconstruir a sua dignidade, família e laços com um local, longe de guerras, fome, perseguição e catástrofes causadas pelos homens.

\section{Referências bibliográficas}

ACSELRAD, Márcio. Por uma visão crítica de minoria. Universidade de Santa Catarina: Crítica Cultura, vol. I, n. I, jan/jun 2006. Disponível em http://www.portaldeperiodicos.unisul.br /index.php/Critica_Cultural/article/view 186/96. Acesso em 14 mar. 2019.

AGÊNCIA DA ONU PARA REFUGIADOS. Dados sobre o refúgio no Brasil. Brasil: Organização das Nações Unidas, 2017. Disponível em https://www.acnur.org/portugues/dados- 


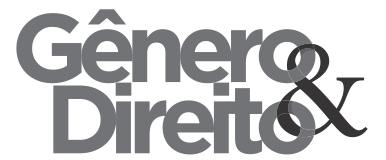

Periódico do Núcleo de Estudos e Pesquisas sobre Gênero e Direito

Centro de Ciências Jurídicas - Universidade Federal da Paraíba

V. 8 - No 03 - Ano 2019

ISSN | 2179-7137 | http://periodicos.ufpb.br/ojs2/index.php/ged/index

sobre-refugio/dados-sobre-refugio-no-

brasil/. Acesso em 14 mai. 2019.

AGRA, Walber de Moura. Curso de Direito Constitucional. Belo Horizonte: Fórum, 2018.

ÁFRICA. Convenção Da Organização De Unidade Africana (OUA) que rege os Aspectos Específicos Dos Problemas Dos Refugiados Em África, de 20 de junho de 1974. Disponível em http://www.refugiados.net/cid_virtual_b kup/asilo2/2couaapr.html. Acesso em 14 mai. 2019.

ALEXY, Robert. Teoria dos Direitos Fundamentais. São Paulo: Malheiros, 2014.

ALTO COMISSARIADO DAS NAÇÕES UNIDAS PARA OS REFUGIADOS. Protocolo de 1967 Relativo ao Estatuto dos Refugiados. Disponível em https://www.acnur.org/fileadmin/Docu mentos/portugues/BD_Legal/Instrument os_Internacionais/Protocolo_de_1967.p df?file=fileadmin/Documentos/portugue s/BD_Legal/Instrumentos_Internacionai s/Protocolo_de_1967. Acesso em 14 mai. 2019.
AMORIM, Fernando Sérgio Tenório de. BARROS; Hugo Marinho Emídio de. Dignidade Humana, Segurança Nacional e os Refugiados ambientais na Lei $\mathrm{n}$. 9.474/1997. Belo Horizonte: Veredas do Direito, vol. 14, n. 28, janeiro/abril de 2017. Disponível em http://www.domhelder.edu.br/revista/in dex.php/veredas/article/view/914/582.

Acesso em 08 mai. 2019.

BARRETO, Luiz Paulo Teles Ferreira. Refúgio no Brasil: a proteção brasileira aos refugiados e seu impacto nas américas. Brasília: ACNUR, Ministério da Justiça, 2010.

BARROSO, Luís Roberto. A dignidade da pessoa humana no direito constitucional contemporâneo: a construção de um conceito jurídico à luz da jurisprudência mundial. Belo Horizonte: Fórum, 2014.

BRASIL. Constituição da República Federativa do Brasil, de 5 de outubro de 1988. Disponível em http://www.planalto.gov.br/ccivil_03/C onstituicao/Constituicao.htm. Acesso em 04 mar. 2019. 
. Decreto $\mathrm{n}^{\mathrm{o}} 592$, de 6 de julho

de 1992. Disponível em

http://www.planalto.gov.br/ccivil_03/de creto/1990-1994/d0592.htm. Acesso em 20 mar. 2019.

. Decreto ${ }^{\circ} 591$, de 6 de julho

de 1992. Disponível em

http://www.planalto.gov.br/ccivil_03/de creto/1990-1994/d0591.htm. Acesso em 20 mar. 2019.

Decreto $\mathrm{n}^{\circ}$ 678, de 6 de novembro de 1992. Disponível em http://www.planalto.gov.br/ccivil_03/de creto/D0678.htm. Acesso em 20 mar. 2019.

. Lei $\mathrm{n}^{\mathrm{o}}$ 9.494, de 10 de setembro de 1997. Disponível em http://www.planalto.gov.br/ccivil_03/lei s/19494.htm. Acesso em 09 mai. 2019.

Decreto $\mathrm{n}^{\circ}$ 6.949, de 25 de agosto de 2009 - $3^{\text {a }}$ Convenção da Organização das Nações Unidas.

Disponível

em

http://www.planalto.gov.br/ccivil_03/_a to2007-2010/2009/decreto/d6949.htm.

Acesso em 14 mai. 2019.
Constituição da República dos Estados Unidos do Brasil, de 16 de julho de 1934. Disponível em http://www.planalto.gov.br/ccivil_03/C onstituicao/Constituicao34.htm. Acesso em 04 mar. 2019.

CÁRITAS BRASILEIRA. Centro de Acolhida de Refugiados. Disponível em http://caritas.org.br/programascaritas/refugiados. Acesso em 14 mai. 2019.

CARMO, Cláudio Márcio. Grupos minoritários, grupos vulneráveis e o problema da (in)tolerância: uma relação linguístico-discursiva e ideológica entre o desrespeito e a manifestação do ódio no contexto brasileiro. São João Del-Rei: Revista do Instituto de Estudos Brasileiros, n. 64, ago/2016, p. 206. Disponível em http://www.scielo.br/pdf/rieb/n64/00203874-rieb-64-0201.pdf. Acesso em 21 mar. 2019.

CORNELLI, Gabrielli. Proteção da Dignidade Humana de Migrantes e Refugiados: uma proposta de intervenção. Florianópolis: Revista Internacional de Filosofia da Moral, vol. 17, n. 1, mai. 2018. Disponível em 


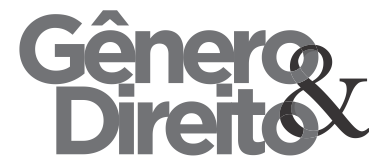

Periódico do Núcleo de Estudos e Pesquisas sobre Gênero e Direito

Centro de Ciências Jurídicas - Universidade Federal da Paraíba

V. 8 - $\mathrm{N}^{\circ} 03$ - Ano 2019

ISSN | 2179-7137 | http://periodicos.ufpb.br/ojs2/index.php/ged/index https://periodicos.ufsc.br/index.php/ethi

c/article/download/1677-

2954.2018v17n1p125/37516. Acesso

em 14 mai. 2019.

ENRICONI, Louise. Imigrante,

Refugiado e Asilado: Quais são as

diferenças? São Paulo: Politize.

Publicado em 13 jul. 2017. Disponível

em

https://www.politize.com.br/refugiadosimigrantes-e-asilados/. Acesso em 14 mai. 2019.

FERNANDES, Bernardo Gonçalves.

Curso de Direito Constitucional. 9 ed.

Salvador: Editora Juspodivm, 2017.

FERREIRA FILHO, Manoel Gonçalves.

Curso de Direito Constitucional. 38 ed.

São Paulo: Saraiva, 2012.

FRANÇA. Declaração Universal de Direitos Humanos, de 10 de dezembro de 1948.

Disponível

em

https://www.unicef.org/brazil/pt/resourc es_10133.html. Acesso em 08 mai. 2019.

GENEBRA. Convenção de Genebra IV, de 21 de outubro de 1950. Disponível em http://www.direitoshumanos.usp.br/inde x.php/Conven\%C3\%A7\%C3\%A3o-de-
102

Genebra/convencao-de-genebra-iv.html. Acesso em 14 mai. 2019.

\section{INSTITUTO DE REINTEGRAÇÃO}

DO REFUGIADO. Conheça a

Instituição. Disponível em http://www.adus.org.br/sobre/. Acesso em 14 mai. 2019.

JUBILUT, Liliana Lyra. A acolhida da população refugiada em São Paulo: a sociedade civil e a proteção dos refugiados. In SILVA, Cesar Augusto S. da. (Org.). Direitos Humanos e Refugiados. Dourados: Ed. UFGD, 2012.

LEITE, Isabela; SOUSA, Viviane. Número de refugiados aumenta em São Paulo, Grande SP e interior do estado. São Paulo: Globo News. Publicado em 19 jun. 2018. Disponível em https://g1.globo.com/sp/sao-

paulo/noticia/numero-de-refugiadosaumenta-em-sao-paulo-grande-sp-einterior-do-estado.ghtml. Acesso em 14 mai. 2019.

MAZZUOLI, Valério de Oliveira. Curso de Direitos Humanos. São Paulo: Método, 2014. 
MELLO, Celso Antônio Bandeira de.

Conteúdo jurídico do princípio da igualdade. 3 ed. São Paulo: Malheiros, 2006.

MELLO, Celso D. de Albuquerque.

Direito Constitucional Internacional. 2 ed. Rio de Janeiro: Renovar, 2000.

MENDES, Gilmar Ferreira. BRANCO, Paulo Gustavo Gonet. Curso de Direito Constitucional. 11 ed. São Paulo: Saraiva, 2016

MENDES, Gilmar Ferreira. Direito de Nacionalidade e Regime Jurídico de Estrangeiro. Porto Alegre: Revista do Programa de Pós-Graduação Mestrado e Doutorado da PUCRS, ano 1, n. 1, out./dez. de 2007. Disponível em http://www.pucrs.br/direito/programade-pos-graduacao-em-

direito/informacoes-adicionais/revistas/. Acesso em 09 mai. 2019.

MISSÃO DE PAZ. História. Disponível em

http://www.missaonspaz.org/menu/que m-somos/historia. Acesso em 14 mai. 2019.
103

NUCLEO DE ESTUDOS DE POPULAÇÃO "ELZA BERQUÓ” (NEPO). Sobre o Projeto. Disponível em https://www.nepo.unicamp.br/pesquisa/ observatorio/index.html. Acesso em 14 mai. 2019.

\section{ORGANIZAÇÃO DAS NAÇÕES}

UNIDAS. Convenção Relativa ao Estatuto dos Refugiados de 1951. Disponível em https://www.acnur.org/fileadmin/Docu mentos/portugues/BDL/Convencao_rela tiva_ao_Estatuto_dos_Refugiados.pdf. Acesso em 08 mai. 2019.

. ONU elogia iniciativas em São Paulo para integrar refugiados e imigrantes. São Paulo: Nações Unidas do Brasil. Publicado em 20 set. 2018. Disponível em https://nacoesunidas.org/onu-elogiainiciativas-em-sao-paulo-para-integrarrefugiados-e-migrantes/. Acesso em 14 mai. 2019.

. Com emprego e aulas de português, refugiados reconstroem suas vidas em São Paulo. São Paulo: Organização das Nações Unidas. Publicado em 14 jan. 2019. Disponível em 
https://nacoesunidas.org/com-emprego-

e-aulas-de-portugues-refugiados-

reconstroem-suas-vidas-em-sao-paulo/.

Acesso em 14 mai. 2019.

OKIN, Susan Moller. Gênero, o público e o privado. Revista dos estudos feministas, Florianópolis, 16(2): 440, maio-ago. 2008.

ORGANIZAÇÃO DOS ESTADOS AMERICANOS. Declaração de Cartagena, de 19 a 22 de novembro de 1984. Disponível em https://www.acnur.org/fileadmin/Docu mentos/portugues/BD_Legal/Instrument os_Internacionais/Declaracao_de_Carta gena.pdf. Acesso em 14 mai. 2019.

PEDRO, Joana. Traduzindo o debate: o uso da categoria gênero na pesquisa histórica. História, 24(1). São Paulo, 2005, p.77-98.

PEREIRA, Luciana Diniz Durães. O direito internacional dos refugiados: análise crítica do conceito de "refugiado ambiental". Belo Horizonte: Pontífica Universidade Católica de Minas Gerais, 2009. Disponível em http://www.biblioteca.pucminas.br/teses
/Direito_PereiraLD_1.pdf. Acesso em 08 mai. 2019.

PIOVESAN. Flávia. O direito de asilo e a proteção internacional dos refugiados. In: ARAÚJO, Nadia de; ALMEIDA, Guilherme Assis. (Coords.) O direito Internacional dos Refugiados: uma perspectiva brasileira. Rio de Janeiro: Renovar, 2001.

RAMOS, André de Carvalho. Curso de Direitos Humanos. 5 ed. São Paulo: Saraiva, 2018.

RIFIOTIS, Theophilos. Nos campos da violência: a diferença e positividade. Santa Catarina: Departamento de Antropologia. Publicado em 13 nov. 2006.

Disponível

em https://www.academia.edu/3059021/No s_campos_da_viol\%C3\%AAncia_difere n\%C3\%A7a_e positividade. Acesso em 14 mai. 2019.

RODRIGUES, Viviane Mozine. Refugiados: os regimes internacionais de direitos humanos e a situação Brasileira In SILVA, Cesar Augusto S. da. (Org.). Direitos Humanos e Refugiados. Dourados: Ed. UFGD, 2012. 
SAADEH, Cyro. EGUCHI, Mônica Mayumi. Convenção Relativa ao Estatuto dos Refugiados - Protocolo sobre o Estatuto dos Refugiados. Disponível em: www.pge.sp.gov.br/centrodeestudos/bib liotecavirtual/direitos/tratado12.htm. Acesso em 08 mai. 2019.

SÃO PAULO. Lei $\mathrm{n}^{\circ} 16.478$, de 8 de julho de 2016. Disponível em https://www.prefeitura.sp.gov.br/cidade/ secretarias/upload/direitos_humanos/MI GRANTES/CONSELHO\%20IMIGRA NTES/Lei\%20Municipal\%2016_478\%2 0de\%208\%20de\%20julho\%20de\%2020 16.pdf. Acesso em 14 mai. 2019.

Decreto $\mathrm{n}^{\circ} 57.5333$, de 15 de dezembro de 2016. Disponível em https://leismunicipais.com.br/a/sp/s/saopaulo/decreto/2016/5753/57533/decreto -n-57533-2016-regulamenta-a-lei-n16478-de-8-de-julho-de-2016-queinstitui-a-politica-municipal-para-apopulacao-imigrante. Acesso em 14 mai. 2019.

SARLET, Ingo Wolfgang. Curso de Direito Constitucional. 11 ed. São Paulo: Saraiva, $7^{\text {a }}$ Ed., 2018.
105

SCOTT, J. Gênero: uma categoria útil de análise histórica. In: Revista Educação \& Realidade. PortoAlegre: v. 15, n. 2, p.7195, Jul/Dez, 1990.

A eficácia dos direitos fundamentais: uma teoria geral dos direitos fundamentais na perspectiva constitucional. 11 ed. Porto Alegre: Livraria do Advogado Editora, 2012.

SÉGUIN, Élida. Minorias e grupos vulneráveis: uma abordagem jurídica. Rio de Janeiro: Forense, 2002.

SPITZCOVSKY, Celso. MOTA, Leda Pereira. Curso de direito constitucional. 7 ed. São Paulo: Damásio de Jesus, 2004.

TAVARES, André Ramos. Curso de Direito Constitucional. 15 ed. São Paulo: Saraiva, 2017.

UNICAMP. Banco Interativo Observatório das Migrações em São Paulo - Imigrantes internacionais com a condição de refúgio registrados no Sistema Nacional de Cadastros e Registros de Estrangeiros (SINCRE), entre 2000-2016, no Estado de São Paulo. Publicado em 2016. Disponível em https://unicamp- 


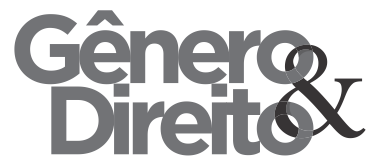

Periódico do Núcleo de Estudos e Pesquisas sobre Gênero e Direito

Centro de Ciências Jurídicas - Universidade Federal da Paraíba V. 8 - No 03 - Ano 2019

arcgis.maps.arcgis.com/apps/opsdashbo

ard/index.html\#/330f0fd0555847daabd2

47d560cbeb4c. Acesso em 14 mai. 2019.

VASCONCELOS, Clever. Curso de Direito Constitucional. 4 ed. São Paulo:

Saraiva, 2017.

VIENA. Declaração e Programa de

Ação de Viena: Conferência Mundial

sobre Direitos Humanos, de 14 a 25 de

junho de 1993. Disponível em

https://www.oas.org/dil/port/1993\%20D

eclara\%C3\%A7\%C3\%A3o\%20e\%20Pr

ograma\%20de\%20Ac\%C3\%A7\%C3\%

A3o\%20adoptado\%20pela\%20Confer\%

C3\%AAncia\%20Mundial\%20de\%20Vi

ena\%20sobre\%20Direitos\%20Humanos

\%20em\%20junho\%20de\%201993.pdf.

Acesso em 14 mai. 2019 